УДК 577.342:53.08:621.372.41

\title{
УЧЕТ СКИН-ЭФФЕКТА ПРИ БЕЗЭЛЕКТРОДНОМ ИССЛЕДОВАНИИ ЭЛЕКТРОПРОВОДНОСТИ ЖИДКОСТИ В КАПИЛЛЯРАХ
}

\author{
о. В. ГУЦУ ${ }^{1}$, в. 3. СЛОБОдян ${ }^{2}$ \\ ${ }^{1}$ Буковинский государственный медицинский университет, \\ Украина, Черновиы, 58000, пл. Театральная, д. 2 \\ ${ }^{2}$ Черновецикий национальный университет им. Ю. Федковича, \\ Украина, Черновщы, 58012, ул. Кочюбинского 2
}

\begin{abstract}
Аннотация. Рассмотрены процессы, которые происходят в установке для безэлектродного измерения электропроводности жидкостей. Проведено экспериментальное исследование зависимости добротности колебательного контура от удельного сопротивления жидкости с использованием электродного и безэлектродного методов измерения. Исследованы частотные зависимости дополнительного затухания $d$ в колебательном контуре, вызванные наличием жидкости с удельным сопротивлением $\rho$ в индуктивно связанном капиллярном соленоиде в диапазоне частот 2,2-8,8 МГц. Показано, что для рассмотренных значений $\rho$ влияние скин-эффекта существенно, и дополнительное затухание описывается формулой $d=-a_{0}(f)+a_{1}(f) \mathrm{\rho}^{-1 / 2}$, где функция $a_{1}(f)$ пропорциональна $f^{3 / 2}$, а функция $a_{0}(f)$ пропорциональна $f^{2}$. Благодаря различным частотным зависимостям функций $a_{1}(f)$ и $a_{0}(f)$ в явном виде получена частотная зависимость относительной глубины скин-слоя в жидком электролите $h / r_{\text {к }}=A(f) \rho^{1 / 2}=a f^{1 / 2} \rho^{1 / 2}$, где $a$ — константа, которая не зависит от частоты и удельного сопротивления жидкости.
\end{abstract}

Ключевые слова: частотная зависимость; скин-эффект; безэлектродный метод; добротность; удельная электропроводность; резонанс частот; колебательный контур; жидкость

\section{ВСТУПЛЕНИЕ}

Безэлектродные исследования электропроводности жидкости являются актуальными для различных отраслей науки и производства, в том числе для технологических процессов с использованием, как химически чистых, так и химически агрессивных жидкостей. Исследование свойств водных растворов электролитов для большого интервала концентраций представляет значительный интерес, как для практики, так и для развития теоретических представлений [1]. Современное состояние исследований электрофизических параметров жидкостей позволяет получать информацию об особенностях поведения и структуры различных растворов [2, 3].

Измерения электропроводности в твердых телах обычно осуществляют с помощью контактов, а в жидкостях - с помощью электродов. Поэтому соответствующие методы измерений часто называют контактными или электродными.

В настоящее время для исследования удельной электропроводности жидкости используются электродные и безэлектродные методы измерений характеристик электропроводных сред. В основе большинства этих методов [4-8] лежит анализ переходных и установившихся процессов, в которых принимает 


\section{БИБЛИОГРАФИЧЕСКИЙ СПИСОК}

1. Jungwirth, P.; Finlayson-Pitts, B. J.; Tobias, D. J. "Introduction: Structure and chemistry at aqueous interfaces," Chemical Rev., Vol. 106, No. 4, p. 1137-1139, 2006. DOI: $\underline{10.1021 / \mathrm{cr} 040382 \mathrm{~h}}$

2. Golnabi, H.; Matloob, M. R.; Bahar, M.; Sharifian, M. "Investigation of electrical conductivity of different water liquids and electrolyte solutions," Iranian Phys. J., Vol. 3, No. 2, p. 24-28, 2009. URI: https://www.sid.ir/en/ journal/ViewPaper.aspx?ID=191551.

3. Zhang, S.; Sun, N.; He, X.; Lu, X.; Zhang, Z. "Physical properties of ionic liquids: database and evaluation," J. Phys. Chem. Ref. Data, Vol. 35, No. 4, p. 1475-1517, 2006. DOI: $10.1063 / 1.2204959$.

4. Популях, К.С. Электронные резонансные измерительные приборы. Харьков: ХГУ, 1961. 138 с.

5. Карандеев, К.Б.; Красиленко, В.А.; Панков, Б.Н.; Соболев, В.С.; Соболевский, К. М. "Методы измерений пассивных электрических параметров,” $A \theta_{-}$ тометрия, № 5, С. 86-100, 1967. URI: https://www. iae.nsk.su/images/stories/5 Autometria/5 Archives/1967 15/86-100.pdf.

6. Охотин, А.С.; Пушкарский, А.С.; Боровикова, Р.П.; Симонов, В.А. Методы измерения характеристики термоэлектрических материалов и преобразователей. М.: Наука, 1974. 168 с.

7. Miller, G. L.; Robinson, D. A. H.; Wiley, J. D. "Contactless measurement of semiconductor conductivity by radio frequency-free-carrier power absorption," Rev. Sci. Instrum., Vol. 47, No. 7, p. 799-806, 1976. DOI: 10.1063/1.1134756.

8. Калинин, В.В.; Казак, В.В. “Способ и устройство для измерения сопротивления водных электролитов," Заводская лаборатория. Диагностика материалов, Т. 8, № 74, С. 46-48, 2008.

9. Гуцул, О. В.; Шаплавский, Н. В.; Слободян, В. 3. "Электромагнитная индукция в биометрии кро- ви," Прикладная радиоэлектроника, Т. 11, № 3, C. 373-377, 2012. URI: http://openarchive.nure.ua/bitst ream/document/1046/1/12.pdf.

10. Gutsul, O. V.; Shaplavsky, N. V.; Buzhdygan, V. V.; Slobodian, V. Z. "A charge of the erythrocyte test by automated method," J. Biomedical Sci. Eng., Vol. 5, No. 4, p. 186-189, 2012. DOI: 10.4236/jbise.2012.54024.

11. Шаплавський, М.В.; Пішак, В.П.; Слободян, О.В.; Коломоє, М.Ю.; Григоришин, П.М. "Безелектродний спосіб автоматизованого вимірювання питомого опору електролітів та біологічних рідин," Пат. 36976 Україна, МПК G 01 N 27/00, заявник та патентовласник Буковинський державний медичний університет МО3 України. № 200807872; заявл. 10.06.08; опубл. 10.11.2008; Бюл. Ізобр., № 21. 6 с. URI: http://uapatents.com/6-36976-bezelektrodnijisposib-avtomatizovanogo-vimiryuvannya-pitomogo-opor u-elektrolitiv-ta-biologichnikh-ridin.html.

12. Гуцул, О. В.; Слободян, В. 3. “Особливості дослідження параметрів рідин електродним та безелектродним методами," Вісник Запорізького національного університету. Серія: Фізико-математичні науки, № 2, С. 21-28, 2013.

13. Батыгин, Ю.В.; Гнатов, А.В.; Барбашова, М.В.; Гаврилова, Т.В.; Степанов, А.А. "Бесконтактный способ измерения удельной электропроводности листовых металлов," Електротехніка і електромеханіка, № 1, C. 69-72, 2012. URI: http://eie.khpi.edu.ua /issue/view/6470.

14. Ащеулов, А. А.; Бучковский, И. А.; Романюк, И. С. "Устройство для бесконтактного измерения электропроводности полупроводников," Технология $u$ конструирование в электронной аппаратуре, № 2, С. 55-57, 2007. URI: http://www.tkea.com.ua/tkea/2007/2 2007/st 017.htm.

15. Латышев, Л. Н.; Иванов, В. В. "Бесконтактный кондуктометр для контроля проводимости скважинной жидкости," Нефтегазовое дело, № 2, С. 1-10, 2013. URI: http://ogbus.ru/article/view/beskontaktnyjkonduktometr-dlya-kontrolya-provodimosti-skvazhinnojzhidkosti. 